\title{
Korespondensi Bahasa Kui, Hamap, dan Kamang di Kabupaten Alor
}

\author{
Salimulloh Tegar Sanubarianto ${ }^{1}$, Christina T. Wekin ${ }^{2}$ \\ ${ }^{1}$ salimulloh@gmail.com, ${ }^{2}$ chr.weking@gmail.com \\ ${ }^{1,2}$ Kantor Bahasa NTT
}

\begin{abstract}
Alor is a district with the unique phenomenon in comparative historical linguistics. The heterogeneity of these languages there has long been interesting to be studied. This study aims to measure the geographical correspondence of Kui, Hamap, and Kamang which are so close geographically. Data were collected by interview method and then analyzed by lexicostatistics. As a result, Kui language has a level of correspondence 18,5\% with Hamap. Kui language has a $14 \%$ level of correspondence with Kamang language . Then, the Hamap language has a $12 \%$ level of correspondence with Kamang language. Furthermore, although the speakers of these three languages life side by side but the the three languages have such a high level of language difference.
\end{abstract}

Keywords: Kui, Hamap, Kamang, correspondence language

Abstrak: Kabupaten Alor merupakan daerah yang memiliki keunikan khususnya dalam keunikan fenomena linguistik historis komparatif. Keheterogenan bahasa yang ada di sana sudah lama menarik untuk diteliti. Penelitian ini bertujuan untuk mengukur korespondensi bahasa Kui, Hamap, dan Kamang yang secara geografis memiliki jarak wilayah yang begitu dekat satu sama lain. Data dikumpulkan dengan metode wawancara yang kemudian dianalisis dengan leksikostatistik. Hasil penelitian menunjukkan bahwa, bahasa Kui memiliki tingkat kekerabatan sebesar 18,5\% dengan bahasa Hamap dan memiliki tingkat kekerabatan sebesar 14\% dengan bahasa Kamang. Selanjutnya, bahasa Hamap memiliki tingkat kekerabatan sebesar 12\% dengan bahasa Kamang. Meskipun penutur ketiga bahasa tersebut berdampingan secara dekat namun ketiga bahasa tersebut memiliki tingkat perbedaan bahasa yang begitu tinggi.

Kata kunci: Kui, Hamap, Kamang, bahasa korespondensi

\section{PENDAHULUAN}

Kabupaten Alor terdiri dari dua pulau utama, yaitu pulau Alor dan Pantar. Dua pulau tersebut terletak di bagian utara pulau Timor dan merupakan salah satu daerah di provinsi Nusa Tenggara Timur yang memiliki bahasa terbanyak. Menurut data Summer Institute of Linguistics (Schapper, 2020), terdapat 19 bahasa yang tersebar di Kabupaten Alor, sedangkan Badan Pengembangan dan Pembinaan Bahasa (Bahasa, 2020) yang melakukan pemetaan bahasabahasa di Indonesia menemukan 23 bahasa di kabupaten ini.

Belakangan ini, Kabupaten Alor menjadi primadona sebagai objek penelitian bahasa. Hal ini disebabkan oleh beberapa faktor. Pertama, keheterogenan bahasa-bahasa yang ada di Kabupaten Alor. Para penutur bahasa yang begitu heterogen di Kabupaten Alor, uniknya tinggal berdampingan hanya berbataskan desa secara administratif. Dengan kata lain, satu desa dan desa 
lain yang bersebelahan dimungkinkan memiliki bahasa (bukan dialek) yang berbeda. Bahkan pada beberapa kasus ditemukan satu desa yang penuturnya memiliki tiga bahasa daerah yang berbeda.

Kedua, belum sepakatnya para linguis, baik dari Indonesia maupun dari luar negeri, dalam hal pengelompokan proto bahasa-bahasa di Alor. Beberapa linguis berpendapat bahwa bahasa-bahasa di Alor merupakan rumpun Melanesia, beberapa yang lain berpendapat bahwa bahasa-bahasa di Alor merupakan rumpun Papua, dan ada juga yang berpendapat bahwa bahasa-bahasa tersebut merupakan rumpun bahasa tersendiri (Klamer, 2014).

Ketiga, masih banyaknya kemungkinan penemuan baru berkaitan dengan bahasa-bahasa di Kabupaten Alor. Hal ini bisa disimpulkan dari pengamatan dua faktor sebelumnya. Kekayaan dan keanekaragaman bahasa di Alor masih menyisakan "lahan" yang begitu luas untuk diteliti, terutama dalam bidang linguistik historis komparatif. Marian Klamer dalam penutup bukunya juga mengungkapkan bahwa bahasa di Alor dan Pantar sedikit beririsan dengan bahasa Proto Austronesia, Proto Papua, dan Proto Lamaholot. Tidak menutup kemungkinan bahasa-bahasa tersebut berasal dari Proto Alor-Pantar yang sampai saat ini belum teridentifikasi (Klamer, 2014).

Bagaimanapun juga bahasa-bahasa di Kabupaten Alor harus segera diidentifikasi, didokumentasi dan dikaji lebih mendalam karena jumlah penutur bahasa itu biasanya tidak sampai mencapai puluhan ribu. Di antara bahasa-bahasa tersebut, ada yang masih aktif digunakan sedangkan sebagian besar sudah tergolong hampir punah karena kurangnya penutur. Bahasa Kui dan Hamap merupakan salah satu bahasa yang tergolong vulnerable atau terancam punah menurut www.endangeredlanguages.com.

Bahasa Kui dan Hamap adalah bahasa yang banyak dituturkan di Alor Daratan. Dua bahasa ini dapat digolongkan sebagai bahasa yang terancam punah, karena meskipun penuturnya tergolong masih banyak, namun jarang ditemui penutur usia muda. Letak bahasa Kui dan Hamap juga bersebelahan dengan bahasa Klon, Abui, dan Kamang. Uniknya penutur kelima bahasa ini memiliki pemertahanan bahasanya sendiri sehingga meski berdekatan bahasa mereka tidak bercampur baur.

Penelitian ini fokus pada korespondensi yang terdapat pada bahasa Kui Hamap, dan Kamang. Penelitian ini adalah penelitian lanjutan untuk mengetahui kekerabatan bahasa-bahasa di Kabupaten Alor. Pada tahun sebelumnya, penelitian dilakukan di Pulau Pantar dengan data berupa kosakata dari bahasa Retta, Kaera, Blagar, dan Teiwa. Kali ini penelitian ditujukan pada bahasa di Alor Daratan, yaitu bahasa Kui, Hamap, dan Kamang, yang nantinya juga akan 
diperluas dengan data dari bahasa Abui dan Klon. Penelitian-penelitian ini akan bermuara pada satu tujuan, yaitu penentuan proto bahasa di Kabupaten Alor.

Pendekatan linguistik historis komparatif digunakan khususnya untuk analisis kekerabatan atau pengelompokan bahasa. Menurut teori ini, bahasa-bahasa yang berkerabat yang memiliki tingkat kekerabatan yang lebih tinggi (persentase kekerabatannya tinggi) dapat dirunut keasalannya sebagai kelompok bahasa yang pada fase historis tertentu memiliki moyang bahasa yang sama sehingga bahasa-bahasa itu dapat diletakkan pada satu simpai dalam pohon kekerabatan bahasa, sedangkan hubungannya dengan bahasa(-bahasa) lain yang berada pada persentase kekerabatan yang lebih rendah, tetapi masih dalam satu rumpun, maka kedua kelompok bahasa itu dapat diletakkan dalam rumpun yang berbeda (Blust, 2018).

Penelitian linguistik historis komparatif sangat erat kaitannya dengan hukum bunyi yang oleh Keraf (Keraf, 1984) diganti istilahnya menjadi korespondensi fonemis atau kesepadanan bunyi. Segmen-segmen yang berkorespondensi bagi glos yang sama baik dari bentuk maupun makna, dalam bermacam-macam bahasa, diperbandingkan satu sama lain. Selanjutnya, Keraf menyatakan bahwa bila sudah diperoleh indikator mengenai korespondensi fonemis, indikator itu harus diuji melalui rekurensi fonemis untuk mendapat korespondensi yang ada.

Berkaitan dengan korespondensi ini, Mahsun (Mahsun, 1995) mengatakan bahwa kekorespondensian dan kevariasian suatu kaidah berkaitan dengan aspek linguistik dan geografi. Disebut aspek korespondensi jika perubahan terjadi karena persyaratan lingkungan linguistik tertentu.

Korespondensi suatu kaidah dapat dibagi dalam empat tingkat berikut.

a. Korespondensi sangat sempurna, jika perubahan itu berlaku untuk semua contoh yang disyarati secara linguistis dan daerah sebaran secara geografi sama.

b. Korespondensi sempurna, jika perubahan itu berlaku pada semua contoh disyarati secara linguistis, namun daerah sebaran secara geografis tidak sama.

c. Korespondensi agak sempurna, jika perubahan itu terjadi pada $3-5$ buah contoh dan daerah sebaran geografisnya sama.

d. Korespondensi tidak sempurna, jika perubahan itu terjadi pada $3-5$ buah contoh dan daerah sebaran geografisnya tidak sama, atau perubahan itu terjadi pada dua buah contoh yang memperlihatkan daerah sebaran geografisnya sama.

Adapun perubahan bunyi yang muncul secara teratur (berupa variasi), antara lain adalah (1) lenisi (pelemahan), (2) epentesis, (3) apokope, (4) sinkope, (5) aferesis, (6) kompresi 
(perampatan), (10) asimilasi, (8) disimilasi, (9) metatesis, dan (10) kontraksi (Mahsun, 1995).

Leksikostatistik adalah suatu teknik dalam pengelompokan bahasa yang lebih cenderung mengutamakan peneropongan kata-kata (leksikon) secara statistik, untuk kemudian berusaha menetapkan pengelompokan itu berdasarkan persentase kesamaan dan perbedaan suatu bahasa dengan bahasa lain Keraf (Keraf, 1984).

Sejauh ini teknik leksikostatistik dianggap sebagai teknik sangat andal untuk mencari korespondensi bunyi antarbahasa. Teknik ini menggunakan pendekatan perhitungan kuantitatif. Derajat kesamaan di antara dua isolek/bahasa yang dibandingkan akan menentukan status apakah isolek/bahasa itu berkerabat erat atau jauh.

Sebagai contoh derajat kekerabatan bahasa ditentukan dalam rentang-rentang persentase sebagai berikut. derajat kekerabatan 100--81\% menentukan hubungan dialek, derajat kekerabatan 80--36\% menentukan hubungan bahasa, derajat kekerabatan 35--12\% menentukan hubungan keluarga bahasa, derajat kekerabatan 12--4\% menentukan hubungan rumpun bahasa, 3--2\% mikrofilum, dan 2--0\% mesofilium (Crowley, 1992).

Dalam metode leksikostatistik, data bahasa yang akan dihitung derajat persamaannya adalah daftar kosakata. Daftar kosakata yang menjadi sasaran jumlahnya bergantung kepentingan penelitian. Akan tetapi dalam penelitian korespondensi yang lebih umum, para pakar umumnya menggunakan daftar kosakata Swadesh. Daftar itu berisikan 200 kosakata dasar yang universal yang mencakup kata ganti, kata bilangan, leksikon anggota badan (sifat dan aktivitasnya), alam dan sekitarnya, dan alat-alat budaya sehari-hari.

Bahasa Kui dituturkan oleh masyarakat yang berada di Desa Prai Bakul, Kecamatan Walakaka, Kabupaten Alor, Provinsi NTT. Berdasarkan hasil penghitungan dialektometri, isolek Kui merupakan sebuah bahasa dengan persentase perbedaan berkisar $81--100 \%$ jika dibandingkan dengan bahasa di sekitarnya, misalnya bahasa Alor dan Dulolong (Bahasa, 2020). Schapper (Schapper, 2020) mengidentifikasi bahasa Kui di NTT dengan nama bahasa Kui (Lerabaing, Masin-Lak). Dinyatakan pula oleh Schapper bahwa bahasa ini terdiri atas tiga dialek, yaitu dialek Kui (Lerabaing, Buruga), Kiramang (Kramang), dan Batulolong

Bahasa Hamap merupakan bahasa yang dituturkan oleh masyarakat yang tinggal di Desa Moru, Kecamatan Alor Barat Daya, Kabupaten Lor, Provinsi NTT. Penutur bahasa ini tinggal di wilayah pesisir, kurang lebih 1-kilometer dari pantai dengan kondisi geografis berupa daratan. Wilayah tutur bahasa Hamap bersebelahan dengan wilayah tutur bahasa Abui yang dituturkan oleh masyarakat yang tinggal di sebelah timur dan selatan Desa Moru, yaitu, Desa Fonatai dan Desa Morba, Failelang. Di sebelah barat terdapat wilayah tutur bahasa Jafoo 
(Kafoa) yang dituturkan masyarakat Desa Wolwal Barat. Di bagian utara terdapat Desa Teluk Mutiara yang masyarakatnya merupakan penutur bahasa Abui. Mayoritas etnik yang menuturkan bahasa Hamap adalah etnik Hamap. Selain penutur bahasa Hamap, yang tinggal di desa ini, juga terdapat masyarakat yang merupakan penutur bahasa Abui, Kui, dan Klon. Berdasarkan perhitungan dialektometri, isolek Hamap merupakan sebuah bahasa dengan persentase perbedaan berkisar 81--100\% jika dibandingkan dengan bahasa di sekitarnya, misalnya bahasa Kabola dan Kamang (Bahasa, 2020). Schapper (Schapper, 2020) mengidentifikasi bahasa Hamap dengan nama bahasa yang sama.

Bahasa Kamang dituturkan oleh masyarakat yang berada di Desa Waisika, Kecamatan Alor Timur, Kabupaten Alor, Provinsi NTT. Menurut pengakuan penduduk, bahasa itu berdampingan dengan bahasa Kula (bahasa Kulatera) dan Kolana di sebelah timur, bahasa Abui (bahasa Aboa) di sebelah barat, dan bahasa Abui dan Kiraman di sebelah selatan. Berdasarkan perhitungan dialektometri, isolek Kamang merupakan sebuah bahasa dengan persentase perbedaan sebesar 81--100\% jika dibandingkan dengan bahasa-bahasa di sekitarnya, misalnya bahasa Alor dan Deing (Bahasa, 2020). Schapper (Schapper, 2020) mengidentifikasi bahasa Kamang di NTT dengan nama bahasa Kamang (Woisika, Waisika). Dinyatakan pula bahwa bahasa ini terdiri atas enam dialek, yaitu Lembur (Limbur, Kawel), Sibo, Kamang, Tiyai, Watang, dan Kamang-kamang.

\section{METODE PENELITIAN}

\section{Penjaringan Data}

Penjaringan data menggunakan daftar tanyaan untuk menjaring data berupa gloss. Daftar tanyaan tersebut adalah Daftar Swadesh yang telah direvisi oleh Blust yang berisi 200 kata dasar baku (Mahsun, 2014). Tahap ini menggunakan data sumber lisan dengan menggunakan informan yang hasilnya kemudian dicatat dan direkam.

\section{Pengklasifikasian Data}

Pada tahap ini, data berupa gloss yang sudah terkumpul direkam dan dicatat secara fonetis pada lembar khusus atau kartu data yang sangat membantu pengkodean atau pengklasifikasian data pada tahap selanjutnya.

\section{Analisis Data}

Data-data kata seasal yang dijaring melalui 200 daftar Swadesh dihitung persentase kesamaannya dengan menggunakan rumus sebagai berikut. 
Jumlah kosakata yang berkorespondensi

x $100 \%$

Jumlah kosakata daftar tanyaan

Untuk menghitung persentase kekognatan antarbahasa maka dari 200 kata Daftar Swadesh minimal diperoleh 174 kata. Setelah diperoleh persentasi kesamaannya selanjutnya dikaji kembali secara leksikostatistik. Dasar teoretis kajian leksikostatistik bahwa (1) ada sebagian kata dasar inti yang sukar berubah jikalau dibandingkan dengan perangkat kata dasar yang lainnya dan (2) harkat retensi (keawetan) dan juga pengikisan kosakata dasar inti setiap seribu tahun selalu konstan pada bahasa manapun. Persentase kekognatan antar-bahasa kemudian ditabulasi dengan model tabulasi menurut Crowley (Crowley, 1992).

\begin{tabular}{|c|c|c|c|c|}
\hline \multicolumn{5}{|l|}{ A } \\
\hline $\mathrm{X}$ & $\mathrm{B}$ & & & \\
\hline $\mathrm{X}$ & $X$ & \multicolumn{3}{|l|}{$\mathrm{C}$} \\
\hline $\mathrm{X}$ & $\mathrm{X}$ & $\mathrm{X}$ & \multicolumn{2}{|l|}{$\mathrm{D}$} \\
\hline $\mathrm{X}$ & $X$ & $\mathrm{X}$ & $\mathrm{X}$ & $\mathrm{E}$ \\
\hline \multicolumn{5}{|c|}{ Keterangan $\mathrm{A}-\mathrm{E}$} \\
\hline & & $X$ & perser & ekognatan \\
\hline
\end{tabular}

Gambar 1. Model Tabulasi Crowley

Dengan proses tabulasi tersebut, akan dilakukan pengelompokkan bahasa-bahasa tersebut menjadi subkelompok-subkelompok yang lebih kecil dengan melihat persentase kekognatan.

\section{HASIL DAN PEMBAHASAN}

Pada pembahasan ini, akan diuraikan secara konseptual tentang metode leksikostatistik, yang lebih ditekankan pada upaya menerangkan tentang langkah-langkah (tenik-teknik) yang dilakukan dalam penerapan metode leksikostatistik yaitu dengan mengumpulkan kosa kata dasar bahasa yang berkerabat; menetapkan dan menghitung pasangan-pasangan mana yang merupakan kata berkerabat; dan menghubungkan hasil perhitungan yang berupa persentase kekerabatan dengan kategori kekerabatan. Selanjutnya dibuat tabulasi yang klasifikasi gloss pada bahasa Retta, Kaera dan Blagar.

\section{Tabulasi Klasifikasi Gloss dengan Kosakata Swadesh}


Tabel 1. Gloss Swadesh Isolek Kui, Hamap, dan Kamang

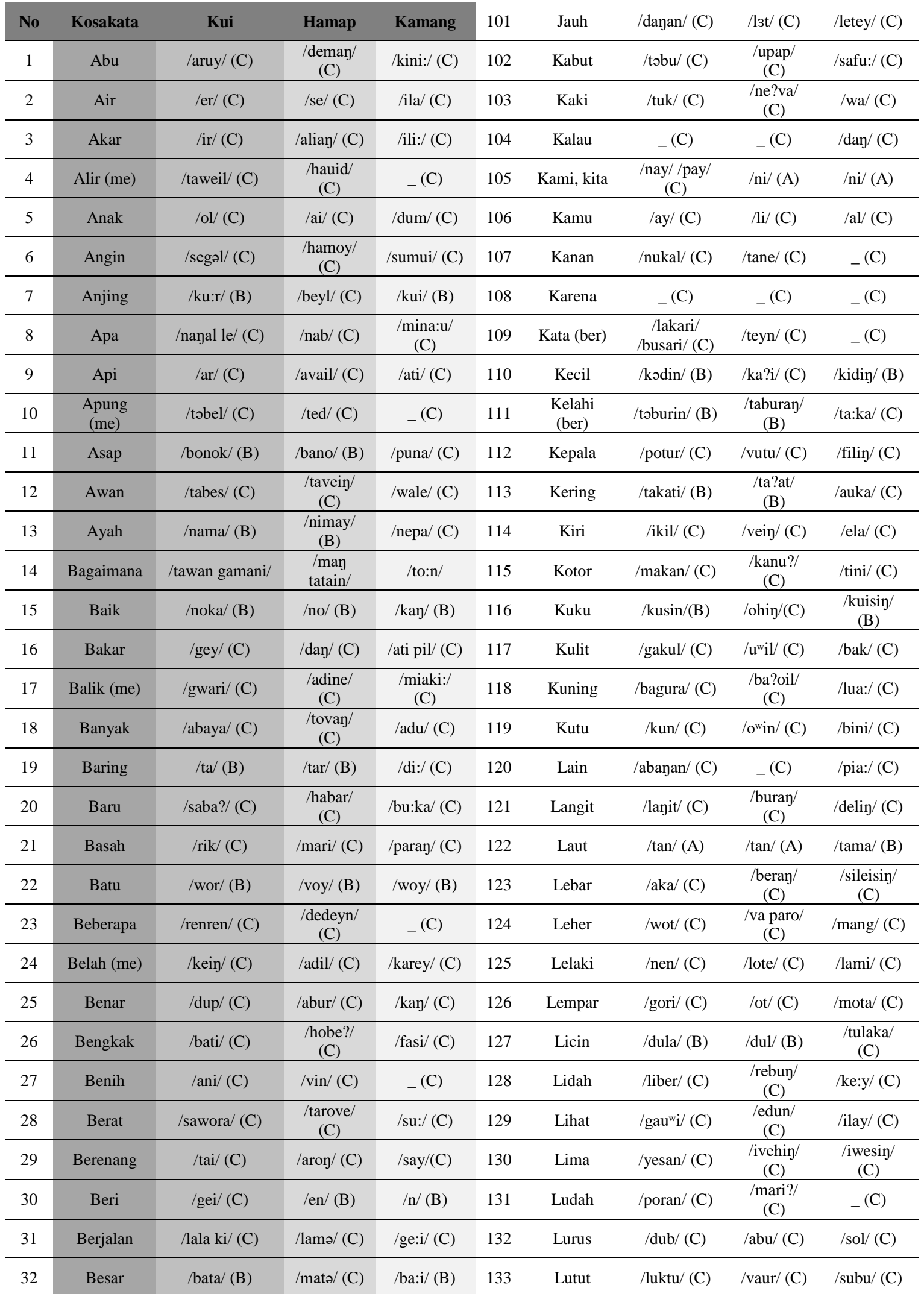




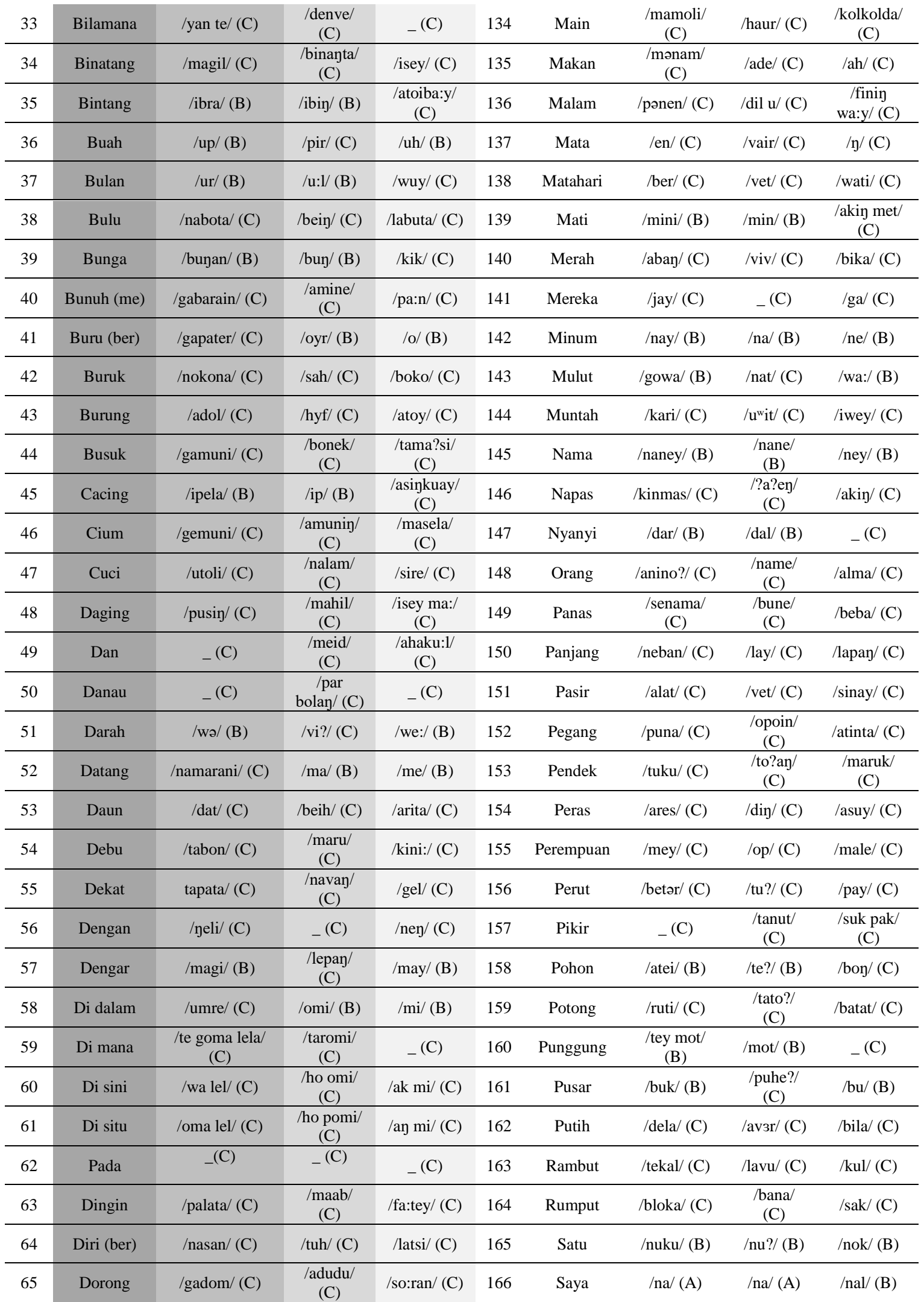




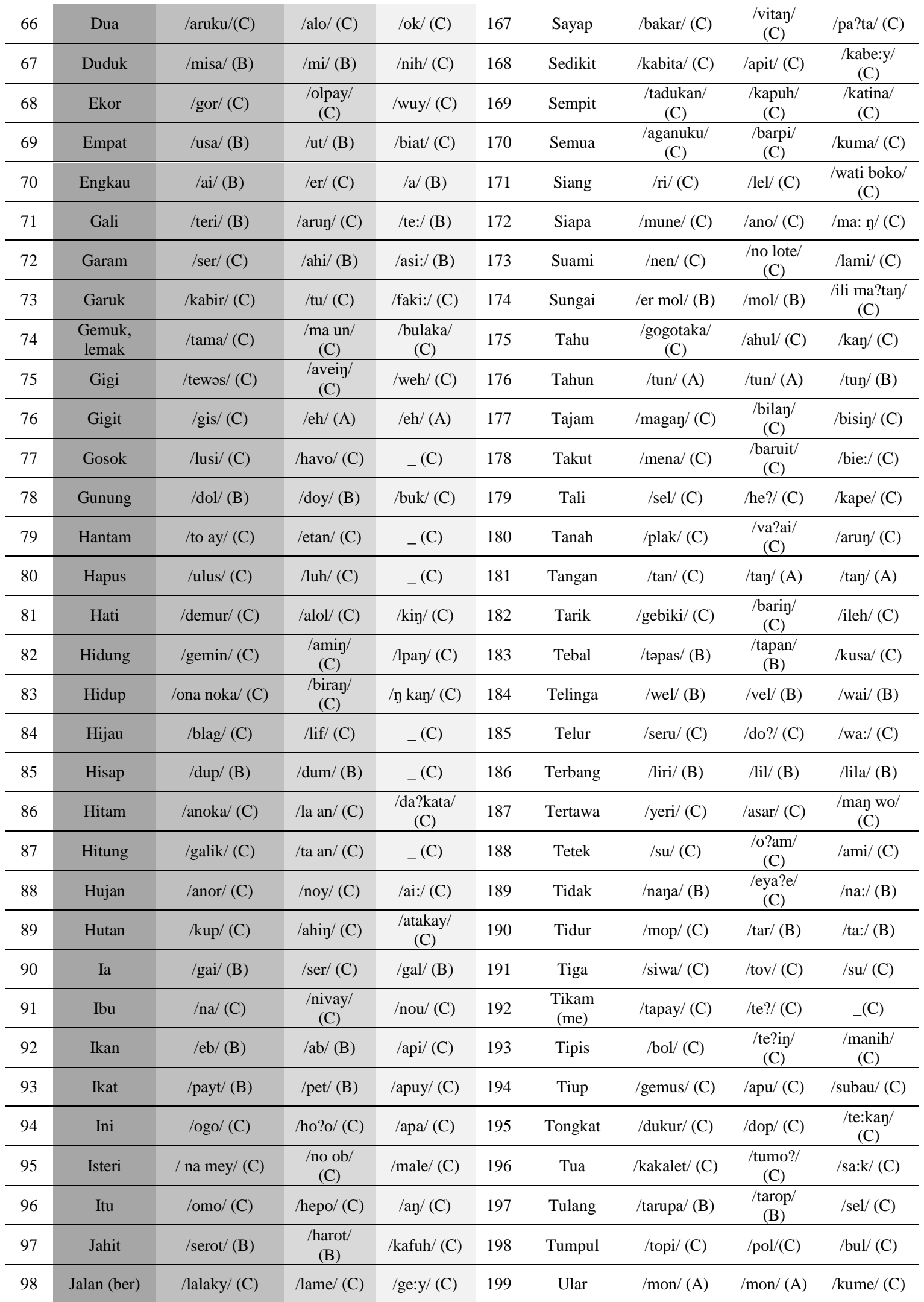




\begin{tabular}{|c|c|c|c|c|c|c|c|c|c|}
\hline 99 & Jantung & $\begin{array}{l}\text { /gabalkubalay/ } \\
\text { (C) }\end{array}$ & $\begin{array}{l}\text { /damur/ } \\
\text { (C) }\end{array}$ & $\begin{array}{c}\text { /bukamay/ } \\
\text { (C) }\end{array}$ & 200 & Usus & /is/ (C) & ${ }_{-}(\mathrm{C})$ & $\begin{array}{l}\text { /ka:puy/ } \\
\text { (C) }\end{array}$ \\
\hline 100 & Jatuh & /muksey/ (C) & - (C) & $\begin{array}{l}\text { /kawaila/ } \\
\text { (C) }\end{array}$ & & & & & \\
\hline
\end{tabular}

Keterangan: Penulisan gloss tidak menggunakan font fonetis untuk mempermudah pengeditan

\section{Kosakata Bahasa Kui dan Hamap yang Berkerabat}

Setelah melakukana pengkodean dan klasifikasi di atas tahap selanjutnya menetapkan dan menghitung pasangan-pasangan mana yang merupakan kata berkerabat antara bahasa Kui dan Hamap, yaitu sebagai berikut.

Tabel 2. Kosakata Kognat Isolek Kui dan Hamap

\begin{tabular}{|c|c|c|c|c|c|c|c|}
\hline No & Kosakata & Kui & Hamap & 19 & Ikat & /payt/ & /pet/ \\
\hline 1 & Asap & /bonok/ & /bano/ & 20 & Ini & logo/ & /ho?o/ \\
\hline 2 & Ayah & /nama/ & /nimay/ & 21 & Jahit & /serot/ & /harot/ \\
\hline 3 & Baik & /noka/ & $/ \mathrm{no} /$ & 22 & Kelahi (ber) & /təburin/ & /taburay/ \\
\hline 4 & Baring & $/ \mathrm{ta} /$ & $/ \operatorname{tar} /$ & 23 & Laut & $/ \tan /$ & $/ \tan /$ \\
\hline 5 & Batu & /wor/ & /voy/ & 24 & Licin & /dula/ & /dul/ \\
\hline 6 & Besar & /bata/ & /matə/ & 25 & Mati & $/ \mathrm{mini} /$ & $/ \mathrm{min} /$ \\
\hline 7 & Bintang & /ibra/ & /ibiy/ & 26 & Minum & /nay/ & $/ \mathrm{na} /$ \\
\hline 8 & Bulan & /ur/ & $/ \mathrm{u}: 1 /$ & 27 & Satu & /nuku/ & /nu?/ \\
\hline 9 & Bunga & /buyan/ & /buy/ & 28 & Saya & /na/ & /na/ \\
\hline 10 & Cacing & /ipela/ & /ip/ & 29 & Sedikit & /kabita/ & /apit/ \\
\hline 11 & Cium & /gemuni/ & /amuniy/ & 30 & Sungai & /er mol/ & $/ \mathrm{mol} /$ \\
\hline 12 & Duduk & $/ \mathrm{misa} /$ & $/ \mathrm{mi} /$ & 31 & Tahun & $/$ tun/ & $/$ tun/ \\
\hline 13 & Empat & /usa/ & /ut/ & 32 & Tangan & $/ \tan /$ & $/ \tan /$ \\
\hline 14 & Gunung & /dol/ & /doy/ & 33 & Tebal & /təpas/ & /tapan/ \\
\hline 15 & Hapus & /ulus/ & /luh/ & 34 & Telinga & /wel/ & /vel/ \\
\hline 16 & Hisap & /dup/ & /dum/ & 35 & Terbang & /liri/ & /lil/ \\
\hline 17 & Hujan & /anor/ & /noy/ & 36 & Tulang & /tarupa/ & /tarop/ \\
\hline 18 & Ikan & /eb/ & /ab/ & 37 & Ular & $/ \mathrm{mon} /$ & $/ \mathrm{mon} /$ \\
\hline
\end{tabular}

Berdasarkan pengumpulan kosa kata bahasa-bahasa antara bahasa Kui dan Hamap Pada table di atas, maka didapat 56 glos yang berkerabat dengan perhitungan sebagai berikut.

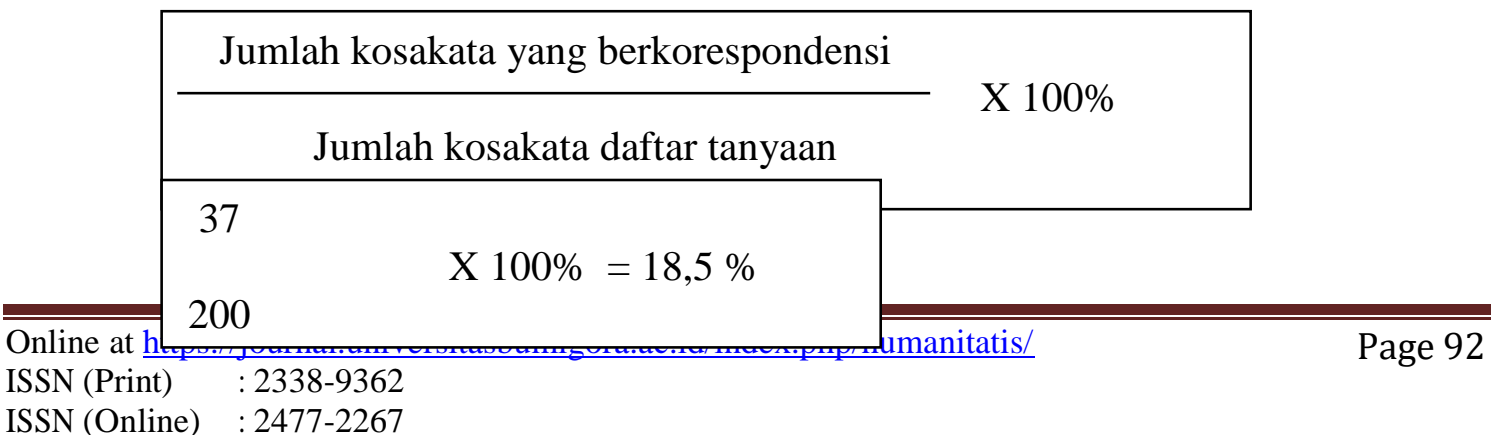


Berdasarkan hasil penghitungan di atas ditemukan tingkat kekerabatan antara bahasa Kui dan Hamap adalah sebesar $18.5 \%$

\section{Kosakata Bahasa Kui dan Kamang yang Berkerabat}

Kemudian dilanjutkan dengan menetapkan dan menghitung pasangan-pasangan mana yang merupakan kata berkerabat antara bahasa Kui dan Kamang.

Tabel 3. Kosakata Kognat Kui dan Kamang

\begin{tabular}{|c|c|c|c|c|c|c|c|}
\hline No & Kosakata & Kui & Kamang & 15 & Kuku & /kusin/ & /kuisin/ \\
\hline 1 & Anjing & /ku:r/ & /kui/ & 16 & Laut & $/ \tan /$ & /tama/ \\
\hline 2 & Ayah & /nama/ & /nepa/ & 17 & Licin & /dula/ & /tulaka/ \\
\hline 3 & Batu & /wor/ & /woy/ & 18 & Minum & /nay/ & /ne/ \\
\hline 4 & Besar & /bata/ & /ba:i/ & 19 & Mulut & /gowa/ & /wa:/ \\
\hline 5 & Buah & /up/ & /uh/ & 20 & Nama & /naney/ & /ney/ \\
\hline 6 & Darah & /wə/ & /we:/ & 21 & Pusar & /buk/ & /bu/ \\
\hline 7 & Dengar & /magi/ & /may/ & 22 & Putih & /dela/ & /bila/ \\
\hline 8 & Engkau & /ai/ & /a/ & 23 & Satu & /nuku/ & /nok/ \\
\hline 9 & Gali & /teri/ & /te:/ & 24 & Saya & /na/ & /nal/ \\
\hline 10 & Ia & /gai/ & /gal/ & 25 & Tahun & /tun/ & /tuy/ \\
\hline 11 & Ibu & /na/ & /nou/ & 26 & Tangan & $/ \tan /$ & /tan/ \\
\hline 12 & $\begin{array}{c}\text { Kami, } \\
\text { kita }\end{array}$ & $\begin{array}{l}\text { /nay/ } \\
\text { /pay/ }\end{array}$ & /ni/ & 27 & Telinga & /wel/ & /wai/ \\
\hline 13 & Kamu & lay/ & /al/ & 28 & Tidak & /naya/ & /na:/ \\
\hline 14 & Kecil & /kədin/ & /kidin/ & & & & \\
\hline
\end{tabular}

Berdasarkan hasil pengumpulan kosa kata bahasa-bahasa antara bahasa Kui dan Kamang maka didapat 28 glos yang berkerabat dengan perhitungan sebagai berikut.

\begin{tabular}{|c|} 
Jumlah kosakata yang berkorespondensi \\
Jumlah kosakata daftar tanyaan
\end{tabular} X 100\%

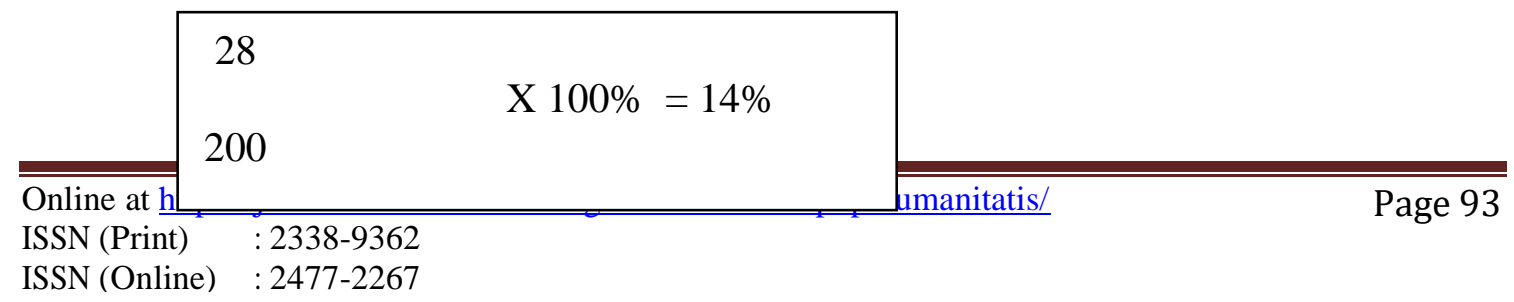


Berdasarkan penghitungan pada table di atas, tingkat kekerabatan antara bahasa Kui dan Hamap adalah $14 \%$

\section{Kosa kata Bahasa Hamap dan Kamang yang Berkerabat}

Kemudian dilanjutkan dengan menetapkan dan menghitung pasangan-pasangan mana yang merupakan kata berkerabat antara bahasa Hamap dan Kamang.

Tabel 4. Kosakata Kognat Isolek Hamap dan Kamang

\begin{tabular}{|c|c|c|c|c|c|c|c|}
\hline No & Kosakata & Hamap & Kamang & 13 & Kami, kita & $/ \mathrm{ni} /$ & $/ \mathrm{ni} /$ \\
\hline 1 & Batu & /voy/ & /woy/ & 14 & Laut & $/ \tan /$ & /tama/ \\
\hline 2 & Beri & len/ & $/ \mathrm{n} /$ & 15 & Lempar & /ot/ & /mota/ \\
\hline 3 & Buru (ber) & /oyr/ & /o/ & 16 & Lima & /ivehiy/ & /iwesin/ \\
\hline 4 & Datang & $/ \mathrm{ma} /$ & $/ \mathrm{me} /$ & 17 & Minum & /na/ & /ne/ \\
\hline 5 & Di dalam & /omi/ & $/ \mathrm{mi} /$ & 18 & Nama & /nane/ & /ney/ \\
\hline 6 & Di sini & /ho omi/ & /ak mi/ & 19 & Satu & /nu?/ & /no?/ \\
\hline 7 & Di situ & /ho pomi/ & /an mi/ & 20 & Saya & /na/ & /nal/ \\
\hline 8 & Duduk & $/ \mathrm{mi} /$ & $/ \mathrm{mih} /$ & 21 & Tahun & /tun/ & /tuy/ \\
\hline 9 & Garam & /ahi/ & /asi/ & 22 & Tangan & $/ \tan /$ & $/ \tan /$ \\
\hline 10 & Gigit & /eh/ & /eh/ & 23 & Terbang & /lil/ & /lila/ \\
\hline 11 & Hujan & /noy/ & /ay/ & 24 & Tidur & $/ \operatorname{tar} /$ & /ta:/ \\
\hline 12 & Ikan & /ap/ & /api/ & & & & \\
\hline
\end{tabular}

Berdasarkan hasil pengumpulan kosa kata antara bahasa Kui dan Kamang di atas, maka didapat 24 glos yang berkerabat dengan perhitungan sebagai berikut.

\begin{tabular}{|c|}
\hline Jumlah kosakata yang berkorespondensi \\
Jumlah kosakata daftar tanyaan
\end{tabular}

$\frac{24}{200} \quad X 100 \%=12 \%$

Berdasarkan table di atas, tingkat kekerabatan antara bahasa Kamang dan Hamap adalah $12 \%$. 


\section{Tingkat Kekerabatan Bahasa Kui, Hamap, dan Kamang}

Setelah perhitungan persentase kata berkerabat antara tiga bahasa tersebut di atas dan diketahui persentase kekerabatannya, lalu persentase itu dihubungkan dengan kategori tingkat kekerabatan bahasa untuk mengetahui kekerabatannya apakah sebagai satu bahasa, keluarga bahasa (subfamily), rumpun bahasa (stock), mikrofilum, mesofilum, atau makrofilum:

Tabel 5. Persentase Tingkat Kekerabatan

\begin{tabular}{|l|l|}
\hline Tingkat Bahasa & Presentase Kata Kerabat \\
\hline Bahasa (language) & 81 ke atas \\
Keluarga (family) & $37-80$ \\
Rumpun (stock) & $12-36$ \\
Mikrofilum & $4-11$ \\
Mesofilum & $1-3$ \\
Makrofilum & 1 ke bawah \\
\hline
\end{tabular}

Sumber: Mahsun, 2014

Berdasarkan hasil tingkat kekerabatan bahasa yang ditemukan, hubungan kekerabatan antara bahasa Kui (BKu), bahasa Hamap (BH) dan bahasa Kamang (BKa) dan berdasarkan perhitungan leksikostatistik terhadap 200 kosa kata dasar Swadesh, maka diperoleh hasil sebagai berikut.

\begin{tabular}{|lll|}
\hline $\mathrm{BKu}$ & & \\
18,5 & $\mathrm{BH}$ & \\
14 & 12 & $\mathrm{BKa}$ \\
\hline
\end{tabular}

Gambar 2. Tabulasi Crowley untuk Isolek Kui, Hamap, dan Kamang

Keterangan:

$\mathrm{BKu}=$ Bahasa Kui

$\mathrm{BH}=$ Bahasa Hamap

$\mathrm{BKa}=$ Bahasa Kamang

Dari perhitungan leksikostatistik di atas diketahui bahwa tingkat kekerabatan bahasa Kui dengan bahasa Hamap 18,5\%, bahasa Kui dan Kamang 14\%, dan bahasa Hamap dengan Kamang $12 \%$. Hasil tersebut dapat disimpulkan bahwa ketiga bahasa tersebut tergolong dalam rumpun (stock) yang sama dan memiliki adalah bahasa yang berdiri sendiri, bukan dialek maupun kreol. Namun, dapat ditelaah lebih lanjut bahwa ketiga bahasa tersebut memiliki tingkat kekerabatan yang sangat kecil. Perlu diadakan penelitian yang lebih lanjut untuk membuktikan ini. Hal ini menjadi sangat unik karena letak geografis penutur ketiga bahasa ini bersebelahan. Jika digambarkan dalam bentuk pohon diagram pohon, maka antara ketiga 
bahasa tersebut tergolong dalam rumpun bahasa yang sama. Untuk lebih jelasnya disajikan dalam bentuk diagram pohon berikut ini.

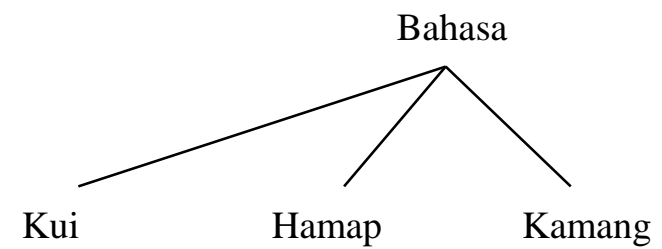

Gambar 3. Diagram Pohon antara bahasa Kui, Hamap, dan Kamang

\section{KESIMPULAN}

Bahasa-bahasa di Kabupaten Alor adalah objek penelitian yang begitu menarik karena banyak aspek yang bisa diulas, salah satunya tingkat kekerabatannya. Keheterogenan bahasabahasa di Alor begitu tinggi, uniknya tingkat kekerabatan bahasa-bahasa tersebut malah begitu rendah. Meski memiliki letak geografis yang berdekatan belum tentu antar-bahasa tersebut berkerabat.

Fakta inilah yang kembali ditemukan dalam penelitian "Tingkat Kekerabatan Bahasa Kui, Hamap, dan Kamang di Kabupaten Alor". Dari hasil penelitian yang telah dilakukan, ketiga bahasa tersebut memiliki tingkat kekerabatan rendah sehingga ketiga bahasa tersebut digolongkan dalam satu rumpun (stock).

Bahasa Kui memiliki tingkat kekerabatan sebesar 18,5\% dengan bahasa Hamap. Bahasa Kui memiliki tingkat kekerabatan sebesar 14\% dengan bahasa Kamang. Lalu, bahasa Hamap memiliki tingkat kekerabatan sebesar 12\% dengan bahasa Kamang. Dari angka-angka tersebut dapat ditelaah bahwa bahasa Kui memiliki kekerabatan yang lebih dekat dengan bahasa Hamap dibanding bahasa Hamap. Dari ketiga bahasa tersebut yang paling dekat kekerabatannya adalah bahasa Kui dengan bahasa Hamap, sedangkan yang paling jauh kekerabatannya adalah bahasa Hamap dengan bahasa Kamang.

\section{DAFTAR PUSTAKA}

Badan Pengembangan dan Pembinaan Bahasa (2020). Peta Bahasa. kemdikbud.go.id. https://petabahasa.kemdikbud.go.id

Blust, R. (2018). Austronesian languages. In The World's Major Languages: Third Edition (Revised Ed). Asia Pacific Linguistics. https://doi.org/10.4324/9781315644936

Crowley, T. (1992). An Introduction to Historical Linguistics. Oxford University Press.

Keraf, G. (1984). Linguistik Bandingan Historis. PT Gramedia. 
Klamer, M. (2014). The Alor-Pantar Language History and Typology. Language Science Press.

Mahsun. (1995). Dialektologi Diakronis: Sebuah Pengantar. Gadjah Mada University Press.

Mahsun. (2014). Metodologi Penelitian Bahasa. Rajagrafindo Persada.

Schapper, A. (2020). Introduction to The Papuan Languages of Timor, Alor and Pantar: Vol. III (Issue June). French National Centre for Scientific Research. 
